\title{
Textbook Selection and Evaluation in EFL Context
}

\author{
Massoud Rahimpour (Corresponding author) \\ The University of Tabriz \& The University of Queensland \\ St. Lucia, Brisbane, Qld 4072, Australia \\ E-mail: rahimpour2011@gmail.com
}

Raheleh Hashemi

The University of Tabriz

E-mail:raheleh.hashemi@gmail.com

Received: July 7, 2011

Accepted: July 29, $2011 \quad$ Published: October 1, 2011

doi:10.5430/wje.v1n2p62

URL: http://dx.doi.org/10.5430/wje.v1n2p62

\begin{abstract}
Decisions related to textbook selection and evaluation are of great importance. The purpose of this study is to evaluate the three English language textbooks currently used at high schools in Iran from the high school English teachers' point of view.

For this purpose, a 46-item questionnaire was developed about the five sections of the textbooks (vocabulary, reading, grammar, language functions, and pronunciation practice), their physical make-up, and practical concerns. Fifty highs school teachers with more than five years of teaching experience were asked to reflect on the questions by checking one of the four options included.

The results indicated that the textbooks are not acceptable from the teachers' point of view considering their five sections, their physical make-up, and some practical concerns.

Keywords: Textbook evaluation, syllabus design, textbook selection, curriculum, EFL context, materials development

\section{Introduction}

It is a fact that selecting and evaluating textbooks in EFL context is of utmost importance. However in Iran, there is limited research conducted to evaluate the textbooks that are already in use or those that are intended for use in future. In most of these studies, the researchers have themselves evaluated different textbooks by means of the checklists and questionnaires suggested by other scholars (Aliakbari, 2004; Jahangard, 2007; Razmjoo, 2007; Azizfar, Koosha and Lotfi, 2010). However, the primary users of textbooks are the teachers. So a comprehensive evaluation can only be carried out while the teachers and their view points are also taken into consideration.
\end{abstract}

\section{Literature Review}

Textbooks play a pivotal role in language classrooms in all types of educational institutions - state schools, colleges, language schools - all over the world. According to Lamie (1999), that is why despite the development of new technologies that allow for higher quality teacher-generated materials, demand for textbooks continues to grow, and the publishing industry responds with new series and textbooks every year. According to Razmjoo (2007) many students working with a textbook feel secure and have a sense of progress and achievement. Cuuingsworth (1995) also argues that textbooks are an effective resource for self-directed learning, an effective resource for presenting materials by the teachers, a source of ideas and activities, a reference source for students, a syllabus that reflects pre-determined learning objectives, and support for less experienced teachers who have yet to gain in confidence.

According to Daoud and Celce-Murcia (1979), information on textbook selection is useful since it is sometimes part of the ESL/EFL teacher's responsibility to select the textbook she/he will use in a given class. Such a decision should be made carefully and systematically, not arbitrarily. They add that even in countries where the choice of the textbook does not directly involve the teacher, teachers may be asked to submit reports on the usefulness of the textbooks they are already making use of. Several possible criteria and procedures for carrying out a sound selection of appropriate 
textbooks have been suggested. However, selecting an appropriate textbook is not a wholly objective process. While many guidelines are suggested, the individual subjective judgments of the teachers are central to it.

Tomlinson (2001) contends that textbook evaluation, on the other hand, is an applied linguistic activity through which teachers, supervisors, administrators and materials developers can make sound judgments about the efficiency of the materials for the people using them. Cunningsworth (1995) and Ellis (1997) declare that textbook evaluation helps teachers move beyond impressionistic assessments and it helps them to acquire useful, accurate, systematic, and contextual insights into the overall nature of textbook material.

\section{Method}

\subsection{Research Questions}

To what extent are the textbooks acceptable in terms of vocabulary presentation and practice?

To what extent are the reading sections acceptable in presentation and practice?

To what extent are the textbooks acceptable in terms of grammar presentation and practice?

To what extent are the textbooks acceptable in terms of presentation and practice of language functions?

To what extent are the textbooks acceptable in terms of pronunciation practice?

To what extent are the textbooks acceptable in terms of physical make-up?

To what extent are the textbooks acceptable considering practical concerns?

\subsection{Materials}

The materials to be evaluated in this study included the three English language textbooks currently taught at high schools throughout the country.

\subsection{Instruments}

The data collection instrument utilized in this study was a questionnaire prepared by the researcher. In order to do so, several questionnaires suggested by different scholars were scrutinized and the items relevant to the textbooks under study were selected. A 48-item questionnaire was so prepared, and a pilot study was conducted with 5 female and 5 male teachers with more than 10 years of teaching experience. The final questionnaire (see Appendix) included 46 questions.

\subsection{Participants}

The population for this study consisted of all the high school English teachers in Tabriz, Iran that are teaching English at high schools at present. The sample included 60 high school English language teachers out of which 50 (30 female and 20 male) accepted to answer the questionnaire.

\subsection{Procedure}

The purpose of this study was to evaluate the English language textbooks currently in use at high schools all over Iran. In order to do so, the following steps were taken. After a pilot study of the questionnaire prepared by the researcher, the 46-item questionnaire about different characteristics of the high school English language textbooks was finalized. 50 English language teachers were given the questionnaires, and let answer the questions on their own. The questionnaires were collected a few days later so that the participants would have enough time to reflect on the questions. Later these survey results were quantified and analyzed in order to answer the research questions.

\section{Results}

For analyzing the survey data collected by means of the questionnaire, first the answers were quantified. Each option of the items was ranked (not at all 1 , not satisfactorily 2 , to some extent 3 , to a great extent 4 ). In order to provide a clear picture of the responses given to the 46 items of the questionnaire, the items were group together and analyzed (Vocabulary, Reading, Grammar, Language Functions, Pronunciation Practice, Physical Make-up, and Practical Concerns). Median was selected as the best representative of central tendency among the three measures of central tendency because of the fact that it is less affected by the extreme data at either end of the scale ( 1 and 4$)$. The individual items of the questionnaire were in fact grouped together and analyzed based on the median of the answers given to them. Table 1 provides the results of descriptive statistics applied.

\section{$<$ Table 1 about here $>$}

As can be seen, the mode and median of the items about the Vocabulary section of the textbooks turned out to be 2 . The mean (2.16) can also be considered as 2 with $95 \%$ confidence level. Since number 2 represents the second option of the 
answers (not satisfactorily) it was be concluded that the textbooks are "not satisfactorily" acceptable in terms of Vocabulary presentation and practice. Similar results were obtained considering the Reading sections and Pronunciation Practice sections of the textbooks. The textbooks are also "not satisfactorily" acceptable in terms of Practical Concerns and their Physical Make-up. However, the mode and median of the items about the "Grammar" section turned out to be 3. The mean (2.52) can be considered as 3 with $95 \%$ confidence level. Since number 3 represents the third option of the answers (to some extent) it can be concluded that the textbooks are "to some extent" acceptable in terms of "Grammar" presentation and practice. Considering the Language Functions sections of the textbooks under analysis, the mode and median of the items about turned out to be 2 . However, the mean (1.85) cannot be considered as 2 with $95 \%$ confidence level, but 1 . Since number 1 represents the first option of the answers (not at all) it can be concluded that the textbooks are "not at all" acceptable in terms of presentation and practice of Language Functions.

\section{Discussion}

The results of this study are in line with the not very comprehensive research literature in the field of textbook selection and evaluation in Iran. . Jahangard (2007) in his analysis of the high school English textbooks has also argued that there is a lack of correspondence between the vocabulary items introduced. He believes the paper of the books is of low quality, and it would be more appealing if colorful pictures of real people and real environment were used in the books. According to Dahmardeh (2009), new words in the textbooks under analysis are presented out of a plausible context as isolated sentences. Sarhady (2009) contends that language functions presented in the textbooks are so context-limited that it is too difficult for students to visualize the situation in which communication has happened. And finally, Azizfar et al (2010) have stated that the materials designers have just focused on the mechanical drills. They believe textbooks are limited to substitution and repetition drills, and students are required to produce simple sentences, and that they are not provided with the opportunity to practice communicatively the language they are learning.

\section{Conclusion}

The findings of this study offer convincing evidence that the English language textbooks that are currently taught at high schools in Iran do not meet the teachers' expectations. The results expand the existing research in the area of textbook selection and evaluation in our country. However, in order to be able to make more sound judgments about different characteristics of these textbooks, more research of this kind needs to be conducted.

\section{Implications}

Findings of this study may offer insights for those involved in educational administrations, syllabus design, curriculum planning, and materials development. Different sections of the textbooks can be modified by the committee of textbook developers of the Iranian high schools in order to improve their quality. Teachers may also get insights from the findings and employ different strategies to compensate for the weak points of the textbooks.

\section{References}

Aliakbari, M. (2004). The Place of culture in the Iranian ELT textbooks in high school level. Paper presented at the 9th Pan-Pacific Association of Applied Linguistics Conference. Namseoul University, Korea.

Azizfar, A., Koosha, M. \& Lotfi, A. R. (2010). An analytical evaluation of Iranian high school ELT textbooks from 1970 to the present. Procedia Social and Beheavioral Sciences, 3, 36-44. http://dx.doi.org/10.1016/j.sbspro.2010.07.010

Cunningsworth, A. (1995). Choosing your coursebook. Oxford: Heinmann.

Dahmardeh, M. (2009). Communicative textbooks: English language textbooks in Iranian secondary high schools. Linguistik, 40(4), 45-61.

Daoud, A. \& Celce-Murcia, M. (1979). Selecting and evaluating a textbook. In M. Celce-Murcia and L. McIntosh (Eds.), Teaching English as a second or foreign language (pp. 302-307).Cambridge, MA: Newbury House Publishers.

Ellis, R. (1997). The empirical evaluation of language teaching materials. ELT Journal, 51(1), 36-42. http://dx.doi.org/10.1093/elt/51.1.36

Jahangard, A. (2007). Evaluation of EFL materials taught at Iranian public high schools. ELT Journal, 9 (2), 130-150.

Lamie, J. M. (1999). Making the textbook more communicative. The Internal TESL Journal, 5(1). Retrieved September 27, 2010, from www.iteslj.org.

Razmjoo, S.A. (2007). High schools or private institutes textbooks? Which fulfill communicative language teaching 
principles in the Iranian context? Asian EFL Journal, 9(4). 126-140.

Sarhady, T. (2009). A critical approach to English material development and language planning in Iran. Indian Journal of Applied Linguistics, 35(2), 143-153.

Tomlinson, B. (2001). Materials development. In R. Carter, \& D. Nunan (Ed.), The Cambridge guide to teaching. English to speakers of other languages (pp. 66-71). Cambridge: Cambridge University Press. http://dx.doi.org/10.1017/CBO9780511667206.010

Table 1: Descriptive Statistics: the results of Medians, Means and Standard Deviations

\begin{tabular}{|l|c|c|c|}
\hline & Median & Mean & SD \\
\hline Vocabulary & 2 & 2.16 & 0.572 \\
\hline Reading & 2 & 2,16 & 0.435 \\
\hline Grammar & 2 & 2.52 & 0.580 \\
\hline $\begin{array}{l}\text { Language } \\
\text { Functions }\end{array}$ & 2 & 1.85 & 0.629 \\
\hline $\begin{array}{l}\text { Pronunciation } \\
\text { Practice }\end{array}$ & 2 & 1.92 & 0.652 \\
\hline $\begin{array}{l}\text { Physical } \\
\text { Make-up }\end{array}$ & 2 & 2.02 & 0.533 \\
\hline $\begin{array}{l}\text { Practical } \\
\text { Concerns }\end{array}$ & 2 & 2.07 & 0.544 \\
\hline
\end{tabular}


Appendix: Questionnaire

\begin{tabular}{|c|c|c|c|c|c|}
\hline \multicolumn{2}{|c|}{ 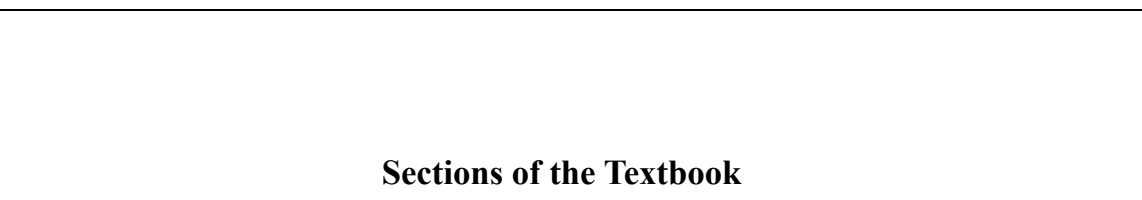 } & \multirow{2}{*}{ 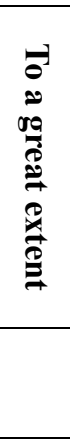 } & \multirow{2}{*}{ 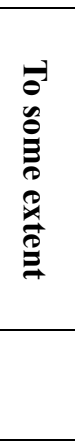 } & \multirow{2}{*}{ 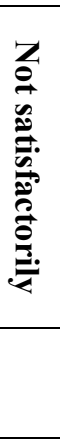 } & \multirow{2}{*}{ 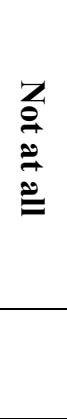 } \\
\hline \multirow{7}{*}{ Vocabulary } & $\begin{array}{l}\text { 1. Does the vocabulary load throughout the textbooks seem } \\
\text { to be reasonable for the students of each level? }\end{array}$ & & & & \\
\hline & $\begin{array}{l}\text { 2. Are the vocabulary items systematically graded from } \\
\text { simple to complex items? }\end{array}$ & & & & \\
\hline & $\begin{array}{l}\text { 3. Are the vocabulary items repeated in subsequent lessons } \\
\text { for reinforcement? }\end{array}$ & & & & \\
\hline & 4. Are the vocabulary items presented in a variety of ways? & & & & \\
\hline & $\begin{array}{l}\text { 5. Are the vocabulary items introduced in motivating and } \\
\text { realistic contexts? }\end{array}$ & & & & \\
\hline & $\begin{array}{l}\text { 6. Do the new items receive sufficient practice through } \\
\text { different kinds of exercises? }\end{array}$ & & & & \\
\hline & $\begin{array}{l}\text { 7. Do the vocabulary exercises promote internalization of } \\
\text { the previously and newly introduced items? }\end{array}$ & & & & \\
\hline \multirow{9}{*}{ Reading } & 8. Are the texts interesting for the students? & & & & \\
\hline & 9. Are the texts authentic pieces of language? & & & & \\
\hline & 10. Do the texts cover a variety of topics and themes? & & & & \\
\hline & $\begin{array}{l}\text { 11. Do the topics dealt with meet local and national } \\
\text { standards? }\end{array}$ & & & & \\
\hline & 12. Are the topics up-to-date? & & & & \\
\hline & $\begin{array}{l}\text { 13. Do the texts serve as a window into learning about the } \\
\text { target language culture? }\end{array}$ & & & & \\
\hline & $\begin{array}{l}\text { 14. Do the texts present information in a way that the } \\
\text { students will understand? }\end{array}$ & & & & \\
\hline & 15. Is the content age-appropriate? & & & & \\
\hline & $\begin{array}{l}\text { 16. Are there enough exercises and activities accompanying } \\
\text { the texts? }\end{array}$ & & & & \\
\hline
\end{tabular}




\section{Sections of the Textbook}

17. Is the number of grammatical points introduced in the textbooks appropriate?

18. Are the grammatical points presented in an increasing level of difficulty?

19. Are the new grammatical points presented in a meaningful context to facilitate understanding?

Grammar

20. Are the explanations easy to understand?

21. Are there enough examples accompanying the explanations?

22. Do the grammatical points receive sufficient practice through exercises and activities?

23. Are the grammatical points repeated and reinforced in subsequent lessons?

24. Is the number of language functions introduced in the textbooks appropriate?

25. Are the language functions presented in meaningful contexts?

Language

Functions

26. Do the language functions introduced accompany practice of different kinds? (e.g. in pairs, in groups) help

27. Are the language functions repeated and reinforced in subsequent lessons?

28. Do the language functions exemplify English in its authentic use?

29. Are the pronunciation points presented in meaningful contexts?

30. Is there enough practice accompanying each pronunciation point introduced?

Pronunciation

Practice

31. Are the pronunciation points repeated and reinforced in subsequent lessons? 


\begin{tabular}{|c|c|c|c|c|}
\hline Physical make-up & $\begin{array}{l}\overrightarrow{0} \\
0 \\
0 \\
\sigma 0 \\
00 \\
0\end{array}$ & 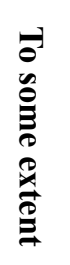 & 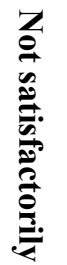 & 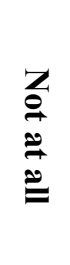 \\
\hline 32. Are the textbook covers attractive? & & & & \\
\hline 33. Is the paper utilized of satisfactory quality? & & & & \\
\hline 34. Are the type size and font appropriate for the learners? & & & & \\
\hline 35. Are there enough illustrations accompanying texts in the textbooks? & & & & \\
\hline 36. Are the illustrations colorful and attractive? & & & & \\
\hline 37. Are the illustrations informative and functional? & & & & \\
\hline 38. Do the illustrations provide appropriate representations of local and national standards? & & & & \\
\hline 39. Do the size and weight of the textbooks seem convenient for the students to handle? & & & & \\
\hline Practical Concerns & & & & \\
\hline 40. Are the objectives explicitly laid out in the introduction part? & & & & \\
\hline 41. Do the textbooks support the goals and objectives of the program and the curriculum? & & & & \\
\hline 42. Are the textbooks sufficiently challenging for the students? & & & & \\
\hline 43. Do the textbooks raise the students' interests in further language study? & & & & \\
\hline $\begin{array}{l}\text { 44. Does each textbook cohere both internally and externally with the other ones in the } \\
\text { series? }\end{array}$ & & & & \\
\hline 45. Do the textbooks contain periodical review sections and exercises throughout lessons? & & & & \\
\hline $\begin{array}{l}\text { 46. Is the methodology proposed to the teachers appropriate for the teaching/learning } \\
\text { situation and the students? }\end{array}$ & & & & \\
\hline
\end{tabular}

